\title{
Como Fazer uma Relação Instigante com a Educação em Saúde
}

How to Make an Exciting Relationship with Health Education

Cómo Hacer una Emocionante Relación con la Educación Sanitaria

Ângela Maria Moreira Canuto ${ }^{1}$

Rubem Alves foi um autor profícuo que escreveu mais de cem obras. Cursou o doutorado em Princeton, mas foi um crítico das publicações científicas, onde a opinião pessoal não tinha valor, e apenas as de outrem, citando a maneira impessoal com que os verbos eram postos. Foi um sonhador que sempre soube recomeçar, sem temer as vicissitudes da vida. Tornou-se um orador que encantava as plateias. Sem abrir mão das suas convicções, era por uns, criticado por não basear as suas conclusões em experimentos científicos, e por outros, exaltados por divulgar pensamentos que o tornavam singular sem ser pretencioso.

A leitura recente de uma biografia cujo título é a cara do biografado: Impossível não viver motivou-me a fazer esta resenha. O autor Gonçalo Júnior, jornalista, conseguiu construir um retrato de uma história de vida onde de tudo houve, desde dramas pessoais e relações de casamento desfeitas, até a descoberta de um novo amor, mas também de doenças que comprometeram uma vida que teimava em viver.

A vida de Rubem foi longa e marcante. Dos diversos temas abordados, a preocupação com a educação foi $o$ escolhido para o momento. Não teria espaço para uma reflexão sobre as quase quinhentas páginas que enchem a vida desse construtor de sonhos.

Pregava a maneira ridendo dicere severum, dizer as coisas sérias 
sorrindo. Dizia-se contra os superlativos na Universidade ou em qualquer outro lugar, portanto argumentava que o reitor deveria deixar de ser "Magnífico" e que o espírito universitário deveria satisfazer-se com um simples "Senhor" ou "Senhor reitor". E explicava: "tratase de uma medida de honestidade linguística: de uma universidade não se pode esperar nada menos que isso - que cada palavra seja usada no seu justo sentido. "Sonhou em ser reitor. E pensou que se assim fosse, ele excluiria o saber por saber e os alunos, professores e funcionários da Unicamp assumiriam a tarefa de cuidar do jardim - "uma festa semanal, em um fim de tarde, todos com rastelos, enxadas, tesouras de podar, vassouras, cestas de lixo, cuidando do jardim". Faria bem para o corpo e a alma de cada um, visto que o jardim era a sua representação máxima da felicidade. Lembrava que segundo o mito bíblico, o mais alto sonho de Deus é um jardim.

As funções de professor e educador são diferentes. Para ele a primeira seria encarada como profissão, ou seja, não era espontâneo, enquanto a segunda, o educador, era pura vocação, fruto de uma virtude que nasce da esperança e do amor em se doar na construção da educação do outro. No mundo moderno a profissão de professor se sobrepõe, porque se valoriza o imediato. $\mathrm{E}$ assim o educador ficou adormecido e deu lugar a função de professor, indivíduo limitado a transferir conhecimento em troca de resultados e estatísticas interessantes para o sistema regente, dominado pelo Estado ou por empresas. Amava as metáforas, e comparou a vida do professor com a vida de um palhaço. A prática de "ensinar" era um ato de alegria, um ofício que deveria ser exercido com paixão e arte assim como a vida de um palhaço tem a missão renovada de divertir. E concluiu: ensinar é fazer daquele momento, único e especial. Escreveu certa vez que o professor deveria agir como um mago e não como um mágico. Não como alguém que ilude, mas sim, como quem acredita e faz crer, que deve fazer acontecer. $\mathrm{O}$ educador fazia a crítica de que ao longo das eras, as escolas foram sendo crescentemente "matematizadas" demais e musicalizadas de menos; "imobilizadas" demais e "dançantes “ de menos; "cientificizadas" demais e " artistificadas" de menos; "funcionalizadas" demais e "espontaneizadas" de menos; "empacotadas " demais e "liberadas" de menos; "programadas e curricularizadas" demais e 
"desrreguladas" e ousadamente “imprevisíveis e criativas" de menos.

O jardim de ideias de Rubem

Alves foi semeado e o transformaram em uma referência de educador para o Brasil. O educador, um mediador apaixonado pelo conhecimento e os alunos construtores do conhecimento e semeadores das melhores sementes. Rubem Alves chega a conclusão, de que a escola sem ser concessiva e sem abrir mão do que é necessário ao aprendizado deveria ser a cada dia uma casa de "sabor" que conduzisse ao "saber", de um "saber" que conduzisse a "sabedoria". Esta, no sentido mais grego da palavra que conduzisse à aventura da santidade. Santidade no seu mais arcaico e original sentido: a realização de cada pessoa do maior desafio da educação, ser um caminho para que cada ser humano experimentasse e realizasse em sua vida a mais importante obra de arte, ou seja, a plenitude de sua própria amorosa pessoa.

\section{Referência}

Júnior G. É uma pena não viver: uma biografia de Rubem Alves. São Paulo: Planeta do Brasil, 2015. 